\title{
Synthesis, characterization and dielectric properties of a novel temperature stable $(1-x) \mathrm{CoTiNb}_{2} \mathrm{O}_{8}-\mathrm{xZnNb}_{2} \mathrm{O}_{6}$ ceramic
}

\author{
Mengjuan $\mathrm{WU}^{a}$, Yingchun $\mathrm{ZHANG}^{a,{ }^{*}}$, Maoqiao XIANG ${ }^{b}$ \\ ${ }^{a}$ School of Materials Science and Engineering, University of Science and Technology Beijing, Beijing 100083, China \\ ${ }^{b}$ State Key Laboratory of Multiphase Complex Systems, Institute of Process Engineering, \\ Chinese Academy of Sciences, Beijing 100190, China
}

Received: October 11, 2018; Revised: November 21, 2018; Accepted: November 29, 2018

(C) The Author(s) 2019.

\begin{abstract}
CoTiNb}_{2} \mathrm{O}_{8}-x \mathrm{ZnNb}_{2} \mathrm{O}_{6}$ microwave dielectric ceramics were prepared via the conventional solid-state reaction route with the aim of reducing the $\tau_{f}$ value and improving the thermal stability. The phase composition and the microstructure were investigated using X-ray diffraction, Raman spectra, and scanning electron microscopy. A set of phase transitions which were induced by composition had been confirmed via the sequence: rutile structure $\rightarrow$ coexistence of rutile and columbite phase $\rightarrow$ columbite phase. For $(1-x) \mathrm{CoTiNb}_{2} \mathrm{O}_{8}-x \mathrm{ZnNb}_{2} \mathrm{O}_{6}$ microwave dielectric ceramics, the addition of $\mathrm{ZnNb}_{2} \mathrm{O}_{6}$ content $(x=0-1)$ led to the decrease of $\mathcal{E}_{\mathrm{r}}$ from 62.98 to 23.94. As a result of the high $Q \times f$ of $\mathrm{ZnNb}_{2} \mathrm{O}_{6}$ ceramics, the increase of $\mathrm{ZnNb}_{2} \mathrm{O}_{6}$ content also led to the lower sintering temperatures and the higher $Q \times f$ values. The $\tau_{f}$ value was reduced from $+108.04(x=0)$ to $-49.31 \mathrm{ppm} /{ }^{\circ} \mathrm{C}$ $(x=1)$. Among them, high density $0.5 \mathrm{CoTiNb}_{2} \mathrm{O}_{8}-0.5 \mathrm{ZnNb}_{2} \mathrm{O}_{6}$ ceramics were obtained at $1175{ }^{\circ} \mathrm{C}$ with excellent microwave dielectric properties of $\varepsilon_{\mathrm{r}} 39.2, Q \times f 40013 \mathrm{GHz}$, and $\tau_{f}+3.57 \mathrm{ppm} /{ }^{\circ} \mathrm{C}$.
\end{abstract}

Keywords: solid-state reaction; $(1-x) \mathrm{CoTiNb}_{2} \mathrm{O}_{8}-x \mathrm{ZnNb}_{2} \mathrm{O}_{6}$ ceramics; crystal structure; microwave dielectric property

\section{Introduction}

In recent years, with the rapid development of modern communication technology, dielectric antenna and microwave integrated circuit substrate, microwave dielectric ceramics which are used as the key material of these electronic components have been developed widely $[1,2]$. For application in microwave frequency field, the dielectric material needs to meet the following three requirements: a large dielectric constant, an excellent quality factor, and a temperature frequency

* Corresponding author.

E-mail: zycustb@163.com coefficient that close to zero. However, it is difficult to meet the above three characteristics at the same time in one material system. Therefore, the adjustment of dielectric properties is very important for practical materials. Baumgarte and Blachnik [3] investigated the compositions of $\mathrm{M}^{2+} \mathrm{M}^{4+} \mathrm{Nb}_{2} \mathrm{O}_{8}\left(\mathrm{M}^{2+}=\mathrm{Be}, \mathrm{Mg}, \mathrm{Ca}\right.$, $\left.\mathrm{Mn}, \mathrm{Co}, \mathrm{Ni}, \mathrm{Cu}, \mathrm{Zn}, \mathrm{Cd} ; \mathrm{M}^{4+}=\mathrm{Ti}, \mathrm{Zr}, \mathrm{Ge}, \mathrm{Sn}\right)$, and among the system, $\mathrm{CoTiNb}_{2} \mathrm{O}_{8}$ ceramics showed excellent microwave dielectric properties: $\mathcal{E}_{\mathrm{r}} \sim 65.4, Q \times f \sim 65300$ $\mathrm{GHz}$, and $\tau_{f} \sim 223.2 \mathrm{ppm} /{ }^{\circ} \mathrm{C}$ [4]. However, the large $\tau_{f}$ value $\left(223.2 \mathrm{ppm} /{ }^{\circ} \mathrm{C}\right)$ is not conducive to its practical application, and needs to be adjusted. Using two kinds of materials with opposite temperature coefficients is a common way to regulate the temperature coefficient of 
the resonant frequency of the material. Many researchers have made attempts in this area, which have obtained good results [5,6]. Nenasheva et al. [7] reported that $\tau_{f}$ was adjusted to $0 \mathrm{ppm} /{ }^{\circ} \mathrm{C}$ when $x=0.66$ in the $(1-x) \mathrm{ZnNb}_{2} \mathrm{O}_{6}-x \mathrm{Zn}_{0.17} \mathrm{Nb}_{0.33} \mathrm{Ti}_{0.5} \mathrm{O}_{2}$ composite. Li et al. [8] reported that $\tau_{f}$ was adjusted to $0.28 \mathrm{ppm} /{ }^{\circ} \mathrm{C}$ in the $(1-x)\left(\mathrm{Na}_{0.5} \mathrm{La}_{0.5}\right) \mathrm{MoO}_{4}-x\left(\mathrm{Na}_{0.5} \mathrm{Bi}_{0.5}\right) \mathrm{MoO}_{4}$ composite. These studies have proved that the method is effective. For the complex phase ceramics with different crystal structures, it has been proved that the formation of solid solution and secondary phase could also be inhibited effectively and could maintain good microwave dielectric properties $[9,10]$. Different from the positive $\tau_{f}$ values of $\mathrm{CoTiNb}_{2} \mathrm{O}_{8}$ ceramics, $\mathrm{ZnNb}_{2} \mathrm{O}_{6}$ ceramics with columbite structure have the negative $\tau_{f}$ values and are in the same niobate system as $\mathrm{CoTiNb}_{2} \mathrm{O}_{8}$ ceramics. Lee et al. [11] reported that the microwave dielectric properties of $\mathrm{ZnNb}_{2} \mathrm{O}_{6}$ reached $\varepsilon_{\mathrm{r}} \sim 25, Q \times f$ $\sim 83700 \mathrm{GHz}$, and $\tau_{f} \sim-56 \mathrm{ppm} /{ }^{\circ} \mathrm{C}$. Therefore, it is estimated that composite ceramics with near zero $\tau_{f}$ values would be obtained by combining $\mathrm{CoTiNb}_{2} \mathrm{O}_{8}$ ceramics and $\mathrm{ZnNb}_{2} \mathrm{O}_{6}$ ceramics.

In this work, $(1-x) \mathrm{CoTiNb}_{2} \mathrm{O}_{8}-x \mathrm{ZnNb}_{2} \mathrm{O}_{6}(x=0-1)$ composite ceramics with different structures were prepared via the traditional solid-state reaction method with the aim of reducing the $\tau_{f}$ value and improving the thermal stability. The phase constitution, microstructure, sintering reaction, and microwave dielectric properties of $(1-x) \mathrm{CoTiNb}_{2} \mathrm{O}_{8}-x \mathrm{ZnNb}_{2} \mathrm{O}_{6}(x=0-1)$ composite were studied in detail.

\section{Experimental}

$\mathrm{CoO}(99 \%), \mathrm{TiO}_{2}(99.9 \%), \mathrm{ZnO}(99 \%)$, and $\mathrm{Nb}_{2} \mathrm{O}_{5}$ (99.99\%) were used as raw materials and purchased from Sinopharm Chemical Reagent Co., Ltd. The raw materials were mixed by a stoichiometric ratio using alcohol as a milling medium for $24 \mathrm{~h}$. The dried powders were calcined at 1200 and $1100{ }^{\circ} \mathrm{C}$ for $4 \mathrm{~h}$ to synthesize $\mathrm{CoTiNb}_{2} \mathrm{O}_{8}$ and $\mathrm{ZnNb}_{2} \mathrm{O}_{6}$. The calcined powders were mixed according to the ratio of $(1-x) \mathrm{CoTiNb}_{2} \mathrm{O}_{8}-x \mathrm{ZnNb}_{2} \mathrm{O}_{6}$ and then ball-milled for $6 \mathrm{~h}$. The slurries were dried at $80{ }^{\circ} \mathrm{C}$ for $1 \mathrm{~h}$ and sieved with 200\# mesh. Polyvinyl alcohol (PVA) was added into the sifted powders and the powders were pressed together into pellets with $10 \mathrm{~mm}$ in diameter and $5 \mathrm{~mm}$ in thickness at a pressure of $150 \mathrm{MPa}$. The pellets were then heated at $500{ }^{\circ} \mathrm{C}$ for $2 \mathrm{~h}$ to discharge the PVA and later sintered in the range of 1150 to $1300{ }^{\circ} \mathrm{C}$ for $4 \mathrm{~h}$.

The crystal structures were characterized by X-ray diffraction (XRD, Rigaku, DMAX-RB, Japan) with $\mathrm{Cu}$ $\mathrm{K} \alpha$ radiation. The microstructure of the sintered ceramics was observed by a scanning electron microscopy (SEM, JSM-6710F, JEOL, Japan) and the composition of the ceramics was analyzed by energy dispersive spectrometer (EDS, NS7, Thermo, USA). The structure parameters were obtained from the Rietveld refinement results of the XRD data using GSAS-EXPGUI software [12]. Raman spectroscopy was performed using a LabRam HR (Jobin-Yvon, France). The density was confirmed by Archimedes methods. Microwave dielectric properties of the ceramics were measured by a network analyzer (8720ES, Agilent, USA) using Hakki-Coleman's dielectric resonator method, modified and improved by Hakki et al. [13-15]. All measurements were obtained in the frequency of 4-12 GHz at room temperature. The temperature coefficients of the resonant frequency were measured in the temperature range from 20 to $80{ }^{\circ} \mathrm{C}$. The $\tau_{f}$ value was calculated using the formula below:

$$
\tau_{f}=\frac{f_{2}-f_{1}}{f_{1}\left(T_{2}-T_{1}\right)}
$$

where $f_{1}$ and $f_{2}$ are the resonant frequencies at $T_{1}$ and $T_{2}$.

\section{Results and discussion}

\section{1 Phase and structure analysis}

Figure 1 shows the XRD patterns of $(1-x) \mathrm{CoTiNb}_{2} \mathrm{O}_{8}-$ $x \mathrm{ZnNb}_{2} \mathrm{O}_{6}$ ceramics sintered at the optimum sintering temperature for $4 \mathrm{~h}$. All the diffraction peaks could be a good index of $\mathrm{CoTiNb}_{2} \mathrm{O}_{8}$ (JCPDS \#52-1875) and $\mathrm{ZnNb}_{2} \mathrm{O}_{6}$ (JCPDS \#37-1371) stage. The composite ceramic samples showed single rutile phase structure of $\mathrm{CoTiNb}_{2} \mathrm{O}_{8}$ ceramics when $x<0.3$. With the increase of $x$, the columbite phase structure of $\mathrm{ZnNb}_{2} \mathrm{O}_{6}$ ceramics appeared gradually. When $x>0.6$, the $\mathrm{CoTiNb}_{2} \mathrm{O}_{8}$ phase disappeared completely. The results indicated that the serious ionic difusion and solid solution reaction had occurred in the system. When $0<x<0.3$, the ceramics were the solid solution based on $\mathrm{CoTiNb}_{2} \mathrm{O}_{8}$ phase. With the increasing $\mathrm{ZnNb}_{2} \mathrm{O}_{6}$ content, the $\mathrm{ZnNb}_{2} \mathrm{O}_{6}$ phase appeared. When $x>0.6$, the ceramics were the solid solution based on $\mathrm{ZnNb}_{2} \mathrm{O}_{6}$ phase. Rietveld refinement was used to analyze the structure evolution in the $(1-x) \mathrm{CoTiNb}_{2} \mathrm{O}_{8}-x \mathrm{ZnNb}_{2} \mathrm{O}_{6}$ system. 


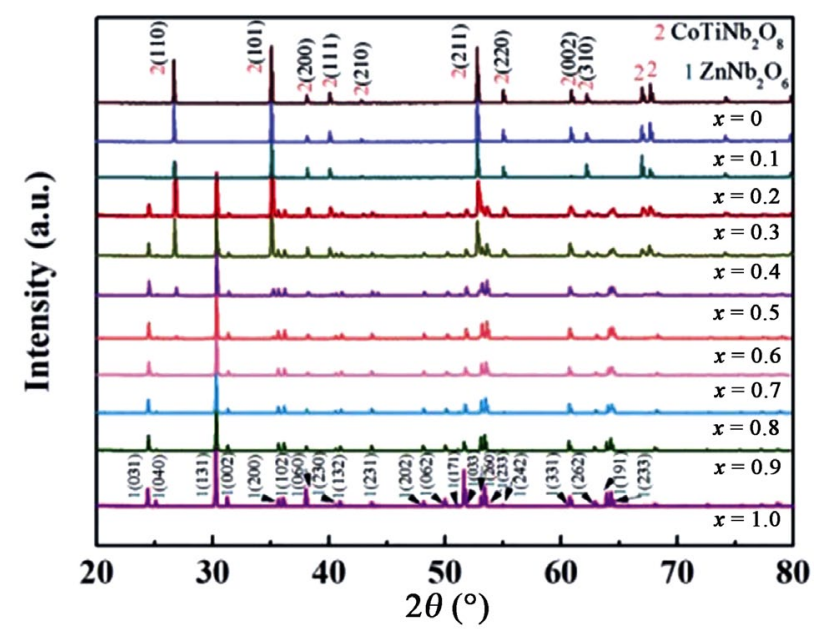

Fig. 1 XRD patterns of $(1-x) \mathrm{CoTiNb}_{2} \mathrm{O}_{8}-x \mathrm{ZnNb}_{2} \mathrm{O}_{6}$ ceramics sintered at the optimum sintering temperature.

The $\mathrm{ZnNb}_{2} \mathrm{O}_{6}(\mathrm{ICSD} \# 36290)$ and the $\mathrm{Zn}_{0.15} \mathrm{Nb}_{0.30} \mathrm{Ti}_{0.55} \mathrm{O}_{2}$ reported by Abrahams et al. [16] were used as the initial models. Lattice parameters and unit-cell volume of the system are revealed in Fig. 2. It was found that there was an expansion in the unit-cell volume with the increase of $\mathrm{ZnNb}_{2} \mathrm{O}_{6}$ content. Figure 3 shows the crystal structure diagram of $\mathrm{CoTiNb}_{2} \mathrm{O}_{8}$ and $\mathrm{ZnNb}_{2} \mathrm{O}_{6}$ ceramics according to the refinement results. The rutile phase structure of $\mathrm{CoTiNb}_{2} \mathrm{O}_{8}$ ceramics belonged to the space group $P_{42 / \mathrm{mnm}}\left(D_{4 \mathrm{~h}}{ }^{14}\right)$. And the unit cell contained one $\mathrm{Co}_{0.5} \mathrm{Ti}_{0.5} \mathrm{NbO}_{4}$ molecule and all $\mathrm{Co}$, $\mathrm{Ti}$, and $\mathrm{Nb}$ cations were coordinated with oxygen ions. The $\mathrm{AO}_{6}$ $(\mathrm{A}=\mathrm{Co}, \mathrm{Ti}, \mathrm{Nb})$ oxygen octahedron was connected by a common top form through $\mathrm{O}_{1}$ and $\mathrm{O}_{2}$. The columbite phase structure of $\mathrm{ZnNb}_{2} \mathrm{O}_{6}$ ceramics belonged to the space group Pbcn (60), the unit cell contained four $\mathrm{ZnNb}_{2} \mathrm{O}_{6}$ molecules. Both $\mathrm{Nb}$ and $\mathrm{Zn}$ formed a distorted octahedron structure with $\mathrm{O}$, and the $\mathrm{NbO}_{6}$ and $\mathrm{ZnO}_{6}$ oxygen octahedron formed a layered structure with the proportion of $1: 2$. It would extend to the direction of the $a$ axis as the ... $\mathrm{ZnNbNbZnNbNb} \mathrm{...}$ mode. The $\mathrm{NbO}_{6}$ oxygen octahedron could form connection by sharing common edges between $\mathrm{O}_{1}$ and $\mathrm{O}_{3}$, and formed a zigzag chain along with the $c$ axis. The adjacent zigzag chains were also connected by $\mathrm{O}_{3}$ in the form of shared vertices, which formed a doublelayer structure that parallel to the $a$ axis. The doublelayer structure was also connected by shared vertice form of $\mathrm{ZnO}_{6}$ oxygen octahedron in the form of $\mathrm{O}_{1}$ and $\mathrm{O}_{2}$, forming a three-dimensional expansion. The $\mathrm{ZnO}_{6}$ oxygen octahedron also formed a zigzag chain along with the $c$ axis in the way of sharing common edges.

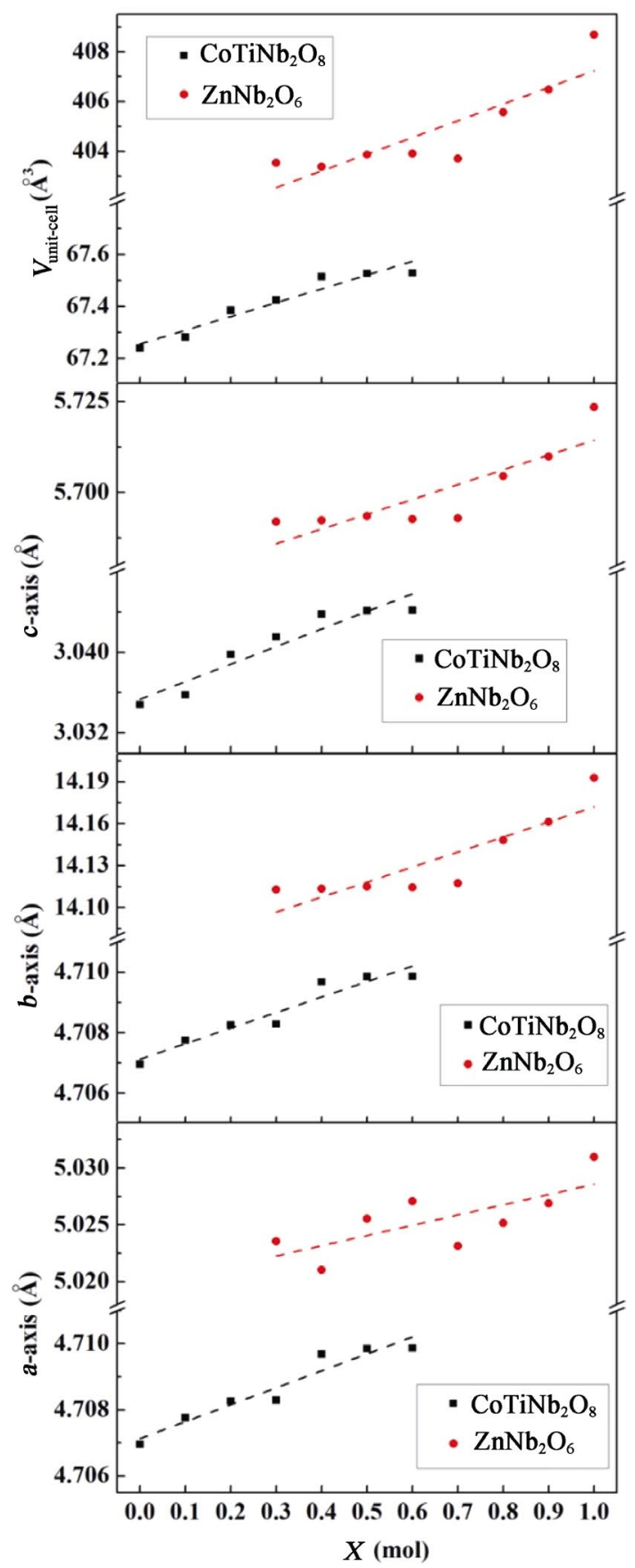

Fig. 2 Lattice parameters and unit-cell volume of $(1-x) \mathrm{CoTiNb}_{2} \mathrm{O}_{8}-x \mathrm{ZnNb}_{2} \mathrm{O}_{6}$ ceramics.

Due to the difference in the polyhedron structure, the chemical reaction between $\mathrm{ZnNb}_{2} \mathrm{O}_{6}$ and $\mathrm{CoTiNb}_{2} \mathrm{O}_{8}$ was inhibited. The good chemical compatibility of $\mathrm{ZnNb}_{2} \mathrm{O}_{6}$ and $\mathrm{CoTiNb}_{2} \mathrm{O}_{8}$ contributed to the successful compensation of dielectric properties, especially for $\tau_{f}$.

\section{2 Raman analysis}

Raman spectra of the $(1-x) \mathrm{CoTiNb}_{2} \mathrm{O}_{8}-x \mathrm{ZnNb}_{2} \mathrm{O}_{6}$ 


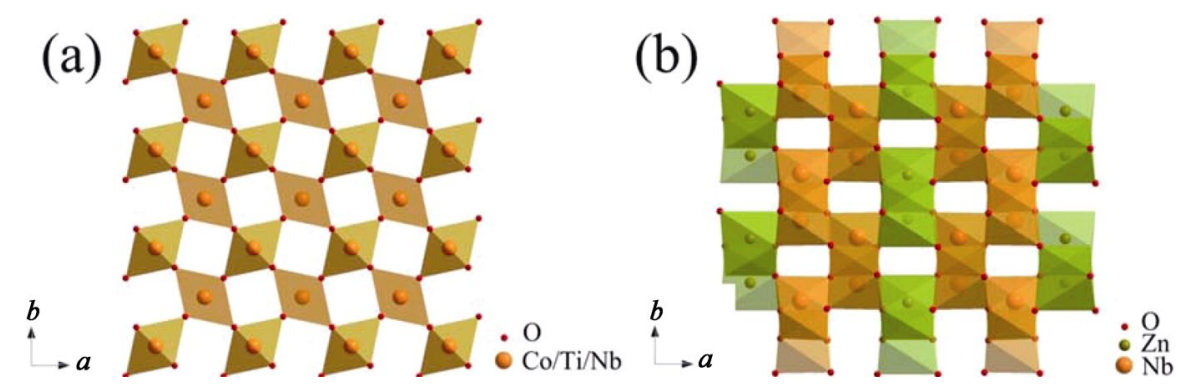

Fig. 3 (a) The rutile octahedral structure of $\mathrm{CoTiNb}_{2} \mathrm{O}_{8}$ ceramics, and (b) the columbite octahedral structure of $\mathrm{ZnNb}_{2} \mathrm{O}_{6}$ ceramics.

ceramics are shown in Fig. 4. For $\mathrm{ZnNb}_{2} \mathrm{O}_{6}$ which belongs to the columbite structure, the theoretical analysis revealed that there are 108 fundamental modes belonging to the following irreducible representations: $13 \mathrm{~A}_{\mathrm{g}}+14 \mathrm{~B}_{1 \mathrm{~g}}+13 \mathrm{~B}_{2 \mathrm{~g}}+14 \mathrm{~B}_{3 \mathrm{~g}}+13 \mathrm{~A}_{\mathrm{u}}+14 \mathrm{~B}_{1 \mathrm{u}}+13 \mathrm{~B}_{2 \mathrm{u}}+14 \mathrm{~B}_{3 \mathrm{u}}$ in which 54 modes $\left(13 \mathrm{~A}_{\mathrm{g}}+14 \mathrm{~B}_{1 \mathrm{~g}}+13 \mathrm{~B}_{2 \mathrm{~g}}+14 \mathrm{~B}_{3 \mathrm{~g}}\right)$ are Raman active and the other $\left(13 A_{u}+14 B_{1 u}+13 B_{2 u}+\right.$ $14 \mathrm{~B}_{3 \mathrm{u}}$ ) are infrared active. Table 1 reveals that the positions correspond to the peaks in the $\mathrm{ZnNb}_{2} \mathrm{O}_{6}$ crystal $[17,18]$. Table 2 illustrates that the Raman vibrational mode assignments of $\mathrm{ZnNb}_{2} \mathrm{O}_{6}$ [18-20]. For $\mathrm{CoTiNb}_{2} \mathrm{O}_{8}$ that belongs to the rutile structure, theoretical analysis [21] shows that there are 15 fundamental modes belonging to the following irreducible representations: $\mathrm{A}_{1 \mathrm{~g}}+\mathrm{A}_{2 \mathrm{~g}}+\mathrm{A}_{2 \mathrm{u}}+\mathrm{B}_{1 \mathrm{~g}}+\mathrm{B}_{2 \mathrm{~g}}+$ $2 \mathrm{~B}_{1 \mathrm{u}}+\mathrm{E}_{\mathrm{g}}+3 \mathrm{E}_{\mathrm{u}}$ in which 4 modes $\left(\mathrm{A}_{1 \mathrm{~g}}+\mathrm{B}_{1 \mathrm{~g}}+\mathrm{B}_{2 \mathrm{~g}}+\mathrm{E}_{\mathrm{g}}\right)$ are Raman active and other 4 modes $\left(\mathrm{A}_{2 \mathrm{u}}+3 \mathrm{E}_{\mathrm{u}}\right)$ are infrared active. The other 3 modes $\left(\mathrm{A}_{2 \mathrm{~g}}+2 \mathrm{~B}_{1 \mathrm{u}}\right)$ are neither Raman active nor infrared active. There are mainly three basic modes that attribute to $\mathrm{CoTiNb}_{2} \mathrm{O}_{8}$ : lattice vibration for $122 \mathrm{~cm}^{-1} ; \mathrm{CoO}_{6}$ octahedra stretching deformation for $278 \mathrm{~cm}^{-1}$ and $\mathrm{Nb}-\mathrm{O}$ symmetric vibration for $684 \mathrm{~cm}^{-1}[22,23]$. When the transition from rutile to columbite took place, the $\mathrm{E}_{\mathrm{g}}$ vibration mode caused by $\mathrm{Ti}-\mathrm{O}$ stretching vibration disappeared at $455 \mathrm{~cm}^{-1}$. Simultaneously, the vibration mode from $\mathrm{NbO}_{6}$ octahedron-symmetrical stretching vibration (located at $887 \mathrm{~cm}^{-1}$ ) belonging to $\mathrm{ZnNb}_{2} \mathrm{O}_{6}$ enhanced gradually and appeared as the main peak. In addition, three extra vibration modes started to appear obviously, where the $\mathrm{A}_{\mathrm{g}}$ mode at $250 \mathrm{~cm}^{-1}$ assigned to $\mathrm{Zn}-\mathrm{O}$ stretching, $\mathrm{O}-\mathrm{Nb}-\mathrm{O}$ bending vibrations, the $\mathrm{A}_{\mathrm{g}}$ mode at $405 \mathrm{~cm}^{-1}$ assigned to $\mathrm{O}-\mathrm{Nb}-\mathrm{O}$ bending vibrations and the $\mathrm{A}_{\mathrm{g}}$ mode at $532 \mathrm{~cm}^{-1}$ assigned to $\mathrm{Nb}-\mathrm{O}$ stretching vibration. The $\mathrm{ZnO}_{6}$ was defined by the $\mathrm{Zn}-\mathrm{O}$ bonds because of the serious distortion of the $\mathrm{ZnO}_{6}$ octahedron [24]. With the increase of $\mathrm{ZnNb}_{2} \mathrm{O}_{6}$ content, the $\mathrm{Zn}-\mathrm{O}$ stretching vibration peaks $(250,272$,

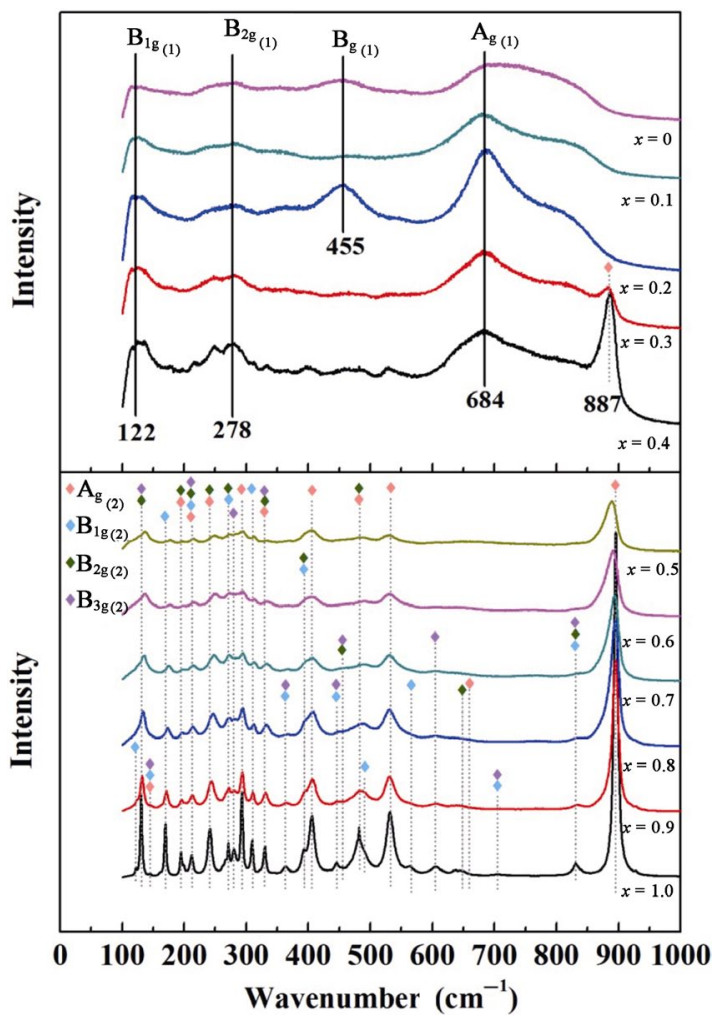

Fig. 4 Raman spectra of $(1-x) \mathrm{CoTiNb}_{2} \mathrm{O}_{8}-x \mathrm{ZnNb}_{2} \mathrm{O}_{6}$ ceramics. $A_{g(1)}, B_{1 g(1)}, B_{2 g(1)}$, and $E_{g(1)}$ were the modes of $\mathrm{CoTiNb}_{2} \mathrm{O}_{8}$ ceramics, $\mathrm{A}_{\mathrm{g}(2)}, \mathrm{B}_{1 \mathrm{~g}(2)}, \mathrm{B}_{2 \mathrm{~g}(2)}$, and $\mathrm{B}_{3 \mathrm{~g}(2)}$ were the modes of $\mathrm{ZnNb}_{2} \mathrm{O}_{6}$ ceramics.

280, 293, 309, and $329 \mathrm{~cm}^{-1}$ ) became stronger gradually. Besides, with the increase of $x$, it can be found that the $\mathrm{A}_{\mathrm{g}}$ vibration mode at $887 \mathrm{~cm}^{-1}$ shifted slightly towards higher wavenumber and then reached $895 \mathrm{~cm}^{-1}$, the $\mathrm{A}_{\mathrm{g}}$ vibration mode shifted to lower wavenumber and finally reached $241 \mathrm{~cm}^{-1}$. The cell volume increased while the content of $\mathrm{ZnNb}_{2} \mathrm{O}_{6}$ increased as shown in Fig. 2, which led to the increase of the atomic distances in the $\mathrm{ZnO}_{6}$ octahedron and this also weakened the covalent bond strength between $\mathrm{Zn}-\mathrm{O}$ bonds [25]. Therefore, the $\mathrm{A}_{\mathrm{g}}$ vibration mode located at $250 \mathrm{~cm}^{-1}$ shifted to the lower wavenumber. 
Table 1 Complied polarized Raman modes for the $\mathrm{ZnNb}_{2} \mathrm{O}_{6}$ single crystal and theoretical date. Reproduced with permission from Ref. [18], (C) AIP Publishing LLC 1977

\begin{tabular}{|c|c|c|c|c|c|c|c|}
\hline \multicolumn{2}{|c|}{$13 \mathrm{~A}_{\mathrm{g}}$} & \multicolumn{2}{|c|}{$14 \mathrm{~B}_{1 \mathrm{~g}}$} & \multicolumn{2}{|c|}{$13 \mathrm{~B}_{2 \mathrm{~g}}$} & \multicolumn{2}{|c|}{$14 \mathrm{~B}_{3 \mathrm{~g}}$} \\
\hline Theo. & Meas. & Theo. & Meas. & Theo. & Meas. & Theo. & Meas. \\
\hline 895 & 895 & 833 & 832 & 833 & 832 & 835 & 832 \\
\hline 650 & 659 & 702 & 705 & 639 & 648 & 712 & 705 \\
\hline 533 & 532 & 571 & 567 & 486 & 481 & 598 & 605 \\
\hline 480 & 481 & 496 & 491 & 454 & 455 & 461 & 455 \\
\hline 399 & 405 & 442 & 445 & 390 & 393 & 440 & 445 \\
\hline 320 & 329 & 389 & 393 & 321 & 329 & 352 & 363 \\
\hline 284 & 293 & 351 & 363 & 273 & 272 & 337 & 330 \\
\hline 251 & 241 & 305 & 309 & 239 & 241 & 278 & 280 \\
\hline 223 & 211 & 266 & 271 & 219 & 211 & 220 & 213 \\
\hline 155 & 194 & 213 & 213 & 200 & 194 & 150 & 145 \\
\hline 145 & 145 & 168 & 169 & 134 & 132 & 135 & 132 \\
\hline 73 & n.o. & 155 & 146 & 100 & n.o. & 84 & n.o. \\
\hline 51 & n.o. & 123 & 122 & 53 & n.o. & 57 & n.o. \\
\hline- & - & 26 & n.o. & - & - & 25 & n.o. \\
\hline
\end{tabular}

Table 2 Raman vibrational mode assignments for $\mathrm{ZnNb}_{2} \mathrm{O}_{6}$

\begin{tabular}{|c|c|c|}
\hline $\begin{array}{l}\text { Wavenumber } \\
\qquad\left(\mathrm{cm}^{-1}\right)\end{array}$ & Symmetry & Mode vibration \\
\hline 213 & $v_{10}\left(\mathrm{~B}_{1 \mathrm{~g}}\right)$ & $\begin{array}{l}\mathrm{O}-\mathrm{Nb}-\mathrm{O} \text { bending, } \mathrm{Nb}-\mathrm{O} \text { stretching, and } \\
\mathrm{Zn}-\mathrm{O} \text { stretching }\end{array}$ \\
\hline 241 & $v_{8}\left(\mathrm{~A}_{\mathrm{g}}\right)$ & $\mathrm{Zn}-\mathrm{O}$ stretching, $\mathrm{O}-\mathrm{Nb}-\mathrm{O}$ bending \\
\hline 272 & $v_{7}\left(\mathrm{~B}_{2 \mathrm{~g}}\right)$ & $\mathrm{Zn}-\mathrm{O}$ stretching, $\mathrm{O}-\mathrm{Nb}-\mathrm{O}$ bending \\
\hline 280 & $v_{8}\left(\mathrm{~B}_{3 \mathrm{~g}}\right)$ & $\mathrm{Zn}-\mathrm{O}$ stretching, $\mathrm{O}-\mathrm{Nb}-\mathrm{O}$ bending \\
\hline 293 & $v_{7}\left(\mathrm{~A}_{\mathrm{g}}\right)$ & $\mathrm{Zn}-\mathrm{O}$ stretching, $\mathrm{O}-\mathrm{Nb}-\mathrm{O}$ bending \\
\hline 309 & $v_{8}\left(\mathrm{~B}_{1 \mathrm{~g}}\right)$ & $\mathrm{Zn}-\mathrm{O}$ stretching, $\mathrm{O}-\mathrm{Nb}-\mathrm{O}$ bending \\
\hline 329 & $v_{6}\left(\mathrm{~A}_{\mathrm{g}}\right)$ & $\begin{array}{l}\mathrm{Nb}-\mathrm{O} \text { stretching, } \mathrm{Zn}-\mathrm{O} \text { stretching, and } \\
\mathrm{O}-\mathrm{Nb}-\mathrm{O} \text { bending }\end{array}$ \\
\hline 363 & $v_{6}\left(\mathrm{~B}_{3 \mathrm{~g}}\right)$ & $\mathrm{O}-\mathrm{Nb}-\mathrm{O}$ bending, $\mathrm{Zn}-\mathrm{O}$ stretching \\
\hline 393 & $v_{4}\left(\mathrm{~B}_{2 \mathrm{~g}}\right)$ & $\mathrm{O}-\mathrm{Nb}-\mathrm{O}$ bending \\
\hline 405 & $v_{5}\left(\mathrm{~A}_{\mathrm{g}}\right)$ & $\mathrm{O}-\mathrm{Nb}-\mathrm{O}$ bending \\
\hline 445 & $v_{5}\left(\mathrm{~B}_{1 \mathrm{~g}}\right)$ & $\mathrm{Nb}-\mathrm{O}$ stretching \\
\hline 481 & $v_{3}\left(\mathrm{~B}_{2 \mathrm{~g}}\right)$ & $\mathrm{Nb}-\mathrm{O}$ stretching, $\mathrm{Zn}-\mathrm{O}$ stretching \\
\hline 532 & $v_{3}\left(\mathrm{~A}_{\mathrm{g}}\right)$ & $\mathrm{Nb}-\mathrm{O}$ stretching vibration \\
\hline 567 & $v_{3}\left(\mathrm{~B}_{1 \mathrm{~g}}\right)$ & $\mathrm{Nb}-\mathrm{O}$ stretching, $\mathrm{Zn}-\mathrm{O}$ stretching \\
\hline 605 & $v_{3}\left(\mathrm{~B}_{3 \mathrm{~g}}\right)$ & $\mathrm{Nb}-\mathrm{O}$ stretching, $\mathrm{Zn}-\mathrm{O}$ stretching \\
\hline 648 & $v_{2}\left(\mathrm{~B}_{2 \mathrm{~g}}\right)$ & $\mathrm{Nb}-\mathrm{O}$ stretching \\
\hline 705 & $v_{2}\left(\mathrm{~B}_{1 \mathrm{~g}}\right)$ & $\mathrm{Nb}-\mathrm{O}$ stretching \\
\hline 832 & $v_{1}\left(\mathrm{~B}_{1 \mathrm{~g}}\right)$ & $\mathrm{Nb}-\mathrm{O}$ anti-symmetric stretching \\
\hline 895 & $v_{1}\left(\mathrm{~A}_{\mathrm{g}}\right)$ & $\mathrm{Nb}-\mathrm{O}$ symmetric stretching \\
\hline
\end{tabular}

Similarly, the $A_{g}$ vibration mode located at $887 \mathrm{~cm}^{-1}$ should shift to the higher wavenumber instead of the lower one. The reason for this phenomenon could be the increase of the symmetry of the crystal because of the sample transition from the disordered phase structure for $x=0.3$ to single columbite phase structure for $x=1$.

\section{3 Morphological analysis}

Figure 5 illustrates the SEM images of $(1-x) \mathrm{CoTiNb}_{2} \mathrm{O}_{8}-$ $x \mathrm{ZnNb}_{2} \mathrm{O}_{6}$ ceramics. Table 3 shows the EDS results of composite ceramics. With the optimized sintering temperature, each component on the ceramic surface was arranged closely. The microstructure shows that the ceramics appear different characteristics on the shape and size of grains with the increase of $\mathrm{ZnNb}_{2} \mathrm{O}_{6}$ content. For samples with $x<0.2$ (Figs. 5(a) and 5(b)), the grain mainly appeared equiaxed structure with large grain size $(>20 \mathrm{~mm})$, and each larger grain seems to merge with many small grains. For $x=0.2$ in Fig. 5(c), the microstructure presents two groups of grains with different grain sizes. The large ones with grain size of $5 \mathrm{~mm}$ distributed very uniformly, and many staircase crystal growth stripes appeared on the surface of the grain. The small ones were very tiny grains with grain sizes of 1-2 mm. As listed in Table 3, the two smaller ones (denoted as A and C) were identified as $\mathrm{CoTiNb}_{2} \mathrm{O}_{8}$ phase, the bigger ones (denoted as B) were identified as the solid solution based on $\mathrm{CoTiNb}_{2} \mathrm{O}_{8}$ phase. For $x=0.3$ and 0.4 in Figs. $5(\mathrm{~d})$ and $5(\mathrm{e})$, the grain sizes reduce to $0.5-2.5 \mathrm{~mm}$. The small grains were identified as $\mathrm{ZnNb}_{2} \mathrm{O}_{6}$ phase and the large polygon-like grains were identified as the solid solution based on $\mathrm{CoTiNb}_{2} \mathrm{O}_{8}$ phase. For those grain boundary system with two phases, there would be pinning effect on the movement of the grain boundary while there were second phase inclusions on the grain boundary. In order to pass through the inclusions in the second phase, the interfacial energy of the system needed to be reduced, resulting in the decrease of the interface continuous progress, which also made the interface become straight. When the driving force of the grain boundary was the same as the resistance force caused by the second phase material, the grain boundary stopped moving and the grain size reached stable. This effect led to the decrease of the grain sizes. When $0.5 \leqslant x<1$ (Figs. 5(f)-5(j)), the energy spectrum results showed that all the grains contain five elements with certain content: $\mathrm{Zn}, \mathrm{Ti}, \mathrm{Co}, \mathrm{Nb}$, and $\mathrm{O}$, which indicated that there will be the diffusion of ions and formation of solid solutions in composite ceramics. The $\mathrm{CoTiNb}_{2} \mathrm{O}_{8}$ phase revealed in Fig. 1 was not 


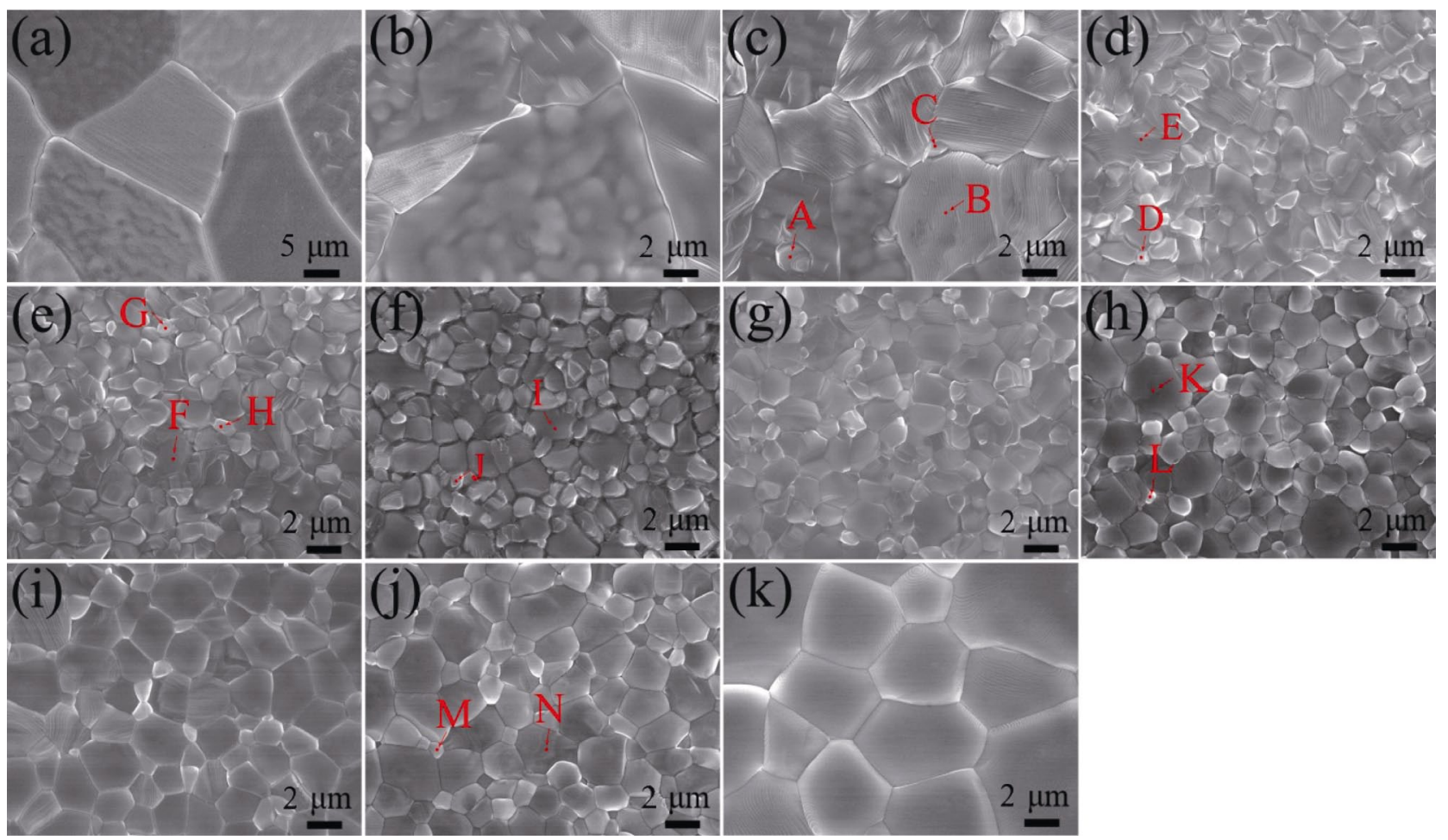

Fig. 5 SEM images of $(1-x) \mathrm{CoTiNb}_{2} \mathrm{O}_{8}-x \mathrm{ZnNb}_{2} \mathrm{O}_{6}$ ceramics with $x=$ (a) 0 , (b) 0.1 , (c) 0.2 , (d) 0.3 , (e) 0.4 , (f) 0.5 , (g) 0.6 , (h) 0.7 , (i) 0.8 , (j) 0.9 , and (k) 1 sintered at $1175{ }^{\circ} \mathrm{C}$ for $4 \mathrm{~h}$.

Table 3 EDS analysis of $(1-x) \mathrm{CoTiNb}_{2} \mathrm{O}_{8}-x \mathrm{ZnNb}_{2} \mathrm{O}_{6}$ ceramics marked in Fig. 5 (Unit: at\%)

\begin{tabular}{ccccccccccccccc}
\hline Spot & A & B & \multicolumn{1}{c}{ C } & \multicolumn{1}{c}{ D } & \multicolumn{1}{c}{ E } & \multicolumn{1}{c}{ F } & G & H & I & J & K & L & M & N \\
\hline Co & 13.58 & 10.55 & 13.43 & 0.89 & 7.46 & 6.54 & 1.27 & 1.78 & 5.69 & 5.97 & 4.80 & 2.85 & 1.96 & 1.71 \\
$\mathrm{Ti}$ & 14.99 & 13.19 & 6.09 & 0.73 & 9.81 & 8.82 & 1.84 & 2.01 & 9.90 & 4.36 & 4.67 & 3.21 & 2.63 & 2.30 \\
$\mathrm{Zn}$ & 0 & 3.23 & 0 & 12.49 & 3.34 & 4.72 & 9.66 & 8.13 & 5.18 & 7.79 & 9.25 & 7.69 & 8.67 & 7.60 \\
$\mathrm{Nb}$ & 42.81 & 44.62 & 44.25 & 38.55 & 32.56 & 34.68 & 30.71 & 26.82 & 30.63 & 31.97 & 39.43 & 32.00 & 32.30 & 30.29 \\
$\mathrm{O}$ & 28.61 & 28.41 & 36.22 & 47.34 & 46.83 & 45.24 & 56.52 & 54.67 & 48.60 & 49.91 & 41.84 & 54.25 & 54.43 & 58.11 \\
\hline
\end{tabular}

shown in Fig. 5, this phenomenon could be caused by the low content of $\mathrm{CoTiNb}_{2} \mathrm{O}_{8}$ phase and it is not obvious in SEM images.

\section{4 Sintering behavior}

The relative densities of $(1-x) \mathrm{CoTiNb}_{2} \mathrm{O}_{8}-x \mathrm{ZnNb}_{2} \mathrm{O}_{6}$ ceramics are depicted in Fig. 6. The relative densities of each composition kept increasing with rising temperature and then decreased until it reached its maximum value. For different values of $x$, the sintering temperatures to obtain the maximum relative densities of the samples decreased with the increase of $x$. The optimum sintering temperature of $\mathrm{CoTiNb}_{2} \mathrm{O}_{8}$ and $\mathrm{ZnNb}_{2} \mathrm{O}_{6}$ ceramics are 1250 and $1175{ }^{\circ} \mathrm{C}$, respectively $[4,11]$. This phenomenon indicated that the increase of $\mathrm{ZnNb}_{2} \mathrm{O}_{6}$ content could reduce the sintering temperature

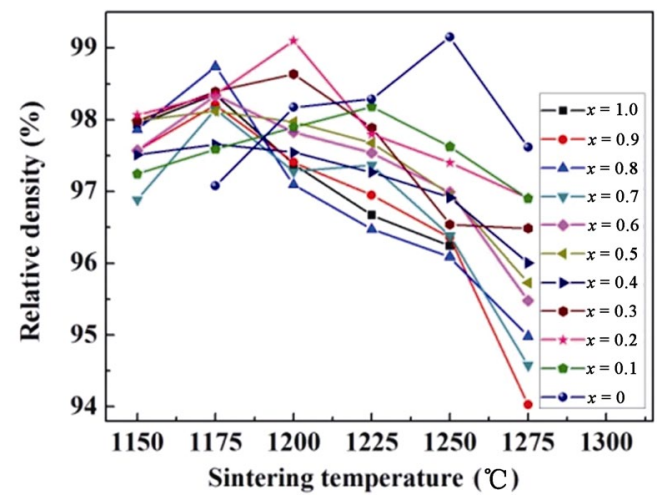

Fig. 6 Bulk densities of $(1-x) \mathrm{CoTiNb}_{2} \mathrm{O}_{8}-x \mathrm{ZnNb}_{2} \mathrm{O}_{6}$ ceramics as a function of sintering temperatures.

of $(1-x) \mathrm{CoTiNb}_{2} \mathrm{O}_{8}-x \mathrm{ZnNb}_{2} \mathrm{O}_{6}$ ceramics which was caused by the lower sintering temperature of $\mathrm{ZnNb}_{2} \mathrm{O}_{6}$ ceramic. 


\section{5 Microwave dielectric properties}

Figure 7(a) shows the dielectric constants of the $(1-x) \mathrm{CoTiNb}_{2} \mathrm{O}_{8}-x \mathrm{ZnNb}_{2} \mathrm{O}_{6}$ ceramics sintered at different temperatures. The changing trend of the dielectric constant of the ceramic along with sintering temperature was same as that of the density: reaching its maximum value at a specific temperature and then decreased. The increase of $\mathrm{ZnNb}_{2} \mathrm{O}_{6}$ content caused the sharp reduction of the dielectric constant values. When $x<0.5$, the dielectric constant values declined from $61.89(x=0.1)$ to $30.7(x=0.5)$. The dielectric constants of the composite can be calculated using the mixture rule [26]:

$$
\operatorname{In} \varepsilon_{\mathrm{r}}=v_{1} \operatorname{In} \varepsilon_{\mathrm{r} 1}+v_{2} \operatorname{In} \varepsilon_{\mathrm{r} 2}
$$

where $\varepsilon_{\mathrm{r}}$ is the dielectric constant of the $(1-x) \mathrm{CoTiNb}_{2} \mathrm{O}_{8}-$ $x \mathrm{ZnNb}_{2} \mathrm{O}_{6}$ ceramics, $v_{1}$ and $v_{2}$ are the volume fractions of $\mathrm{CoTiNb}_{2} \mathrm{O}_{8}$ and $\mathrm{ZnNb}_{2} \mathrm{O}_{6}$, respectively; $\varepsilon_{\mathrm{r} 1}$ and $\varepsilon_{\mathrm{r} 2}$ are the dielectric constant of $\mathrm{CoTiNb}_{2} \mathrm{O}_{8}$ and $\mathrm{ZnNb}_{2} \mathrm{O}_{6}$, respectively. The values of the calculated dielectric constant and the measured dielectric constant are depicted in Fig. 7(b). The calculated dielectric constant values were lower than the measured values while the content of $\mathrm{ZnNb}_{2} \mathrm{O}_{6}$ was less than $50 \%$. For
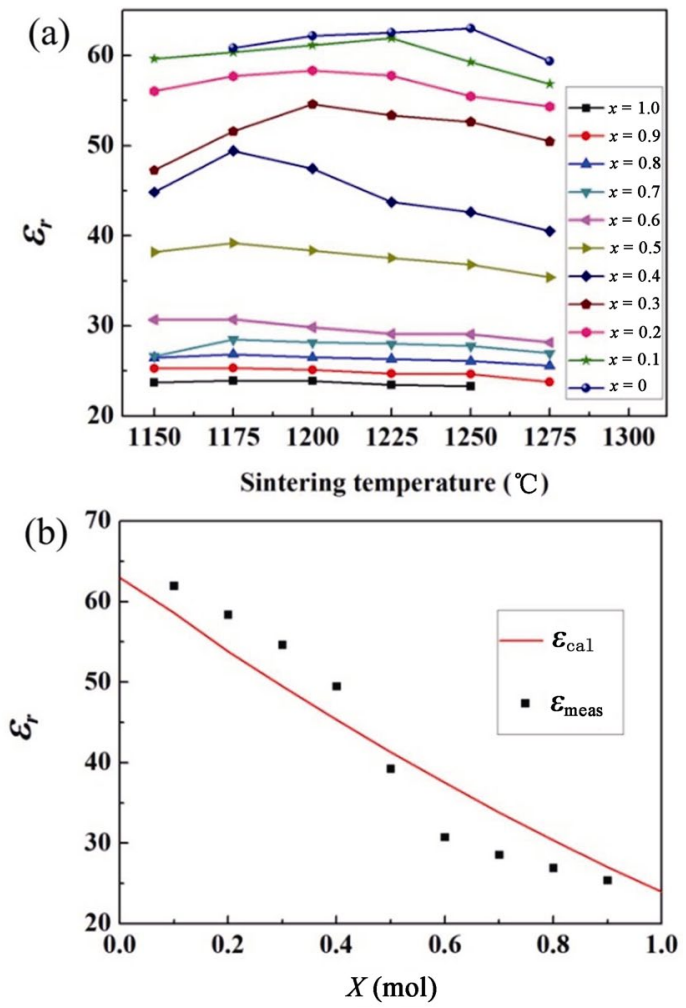

Fig. 7 (a) Dielectric constants of $(1-x) \mathrm{CoTiNb}_{2} \mathrm{O}_{8}-$ $x \mathrm{ZnNb}_{2} \mathrm{O}_{6}$ ceramics as a function of sintering temperatures, and (b) the change of dielectric constants of $(1-x) \mathrm{CoTiNb}_{2} \mathrm{O}_{8}-$ $x \mathrm{ZnNb}_{2} \mathrm{O}_{6}$ ceramics vs. $x$. further increasing $\mathrm{ZnNb}_{2} \mathrm{O}_{6}$ content, the calculated dielectric constant values were higher than the measured values. Apart from these differences, the calculated dielectric constant and measured dielectric constant showed the similar trend. The main reason of the deviation between the measured values and the theoretical values was that the low content of ingredients were dissolved into the high content phase, and partly formed the solid solution while $x$ was either too small or too large, so the dielectric properties were different from the mixture rule of the composite materials. It mainly depended on the crystal structure of the main phase. According to the Raman result, when $0<x \leqslant 0.4$, the main phase was $\mathrm{CoTiNb}_{2} \mathrm{O}_{8}$, the $\varepsilon_{\mathrm{r}}$ values were skewed to the $\varepsilon_{\mathrm{r}}$ value of $\mathrm{CoTiNb}_{2} \mathrm{O}_{8}$. For $0.5 \leqslant x<1$, the main phase was $\mathrm{ZnNb}_{2} \mathrm{O}_{6}$, the $\varepsilon_{\mathrm{r}}$ values were biased to the $\varepsilon_{\mathrm{r}}$ value of $\mathrm{ZnNb}_{2} \mathrm{O}_{6}$.

Figure 8 (a) demonstrates $Q \times f$ values of the $(1-x) \mathrm{CoTiNb}_{2} \mathrm{O}_{8}-x \mathrm{ZnNb}_{2} \mathrm{O}_{6}$ ceramics as functions of $x$ and sintering temperatures. With the increase of $x$, the variation of $Q \times f$ values of the ceramics along with the sintering temperatures was the same as dielectric constants. This phenomenon was mainly ascribed to the low sintering temperature of $\mathrm{ZnNb}_{2} \mathrm{O}_{6}$. Figure $8(\mathrm{~b})$ gives the relationship between the $Q \times f$ values of the composite ceramics and the change of $x$ values. For samples of $x=0.1$, the $Q \times f$ values were $38,220 \mathrm{GHz}$ which matched the theoretical value quite well. For samples of $0.2<x<0.4$, the $Q \times f$ values reduced to lower than $38,220 \mathrm{GHz}$, which deviated from theoretical value seriously. Upon further increasing $\mathrm{ZnNb}_{2} \mathrm{O}_{6}$ content, the $Q \times f$ values began to increase again. When it comes to $x=1$, the $Q \times f$ values reached $96,392 \mathrm{GHz}$. The $Q \times f$ values of the composite can be calculated using the mixture rule [27]:

$$
Q^{-1}=v_{1} Q_{1}^{-1}+v_{2} Q_{2}^{-1}
$$

where $Q^{-1}$ is the quality factor of the $(1-x) \mathrm{CoTiNb}_{2} \mathrm{O}_{8}$ $x \mathrm{ZnNb}_{2} \mathrm{O}_{6}$ ceramics, $v_{1}$ and $v_{2}$ are the volume fractions of $\mathrm{CoTiNb}_{2} \mathrm{O}_{8}$ and $\mathrm{ZnNb}_{2} \mathrm{O}_{6}$, respectively; $Q_{1}^{-1}$ and $Q_{2}^{-1}$ are the quality factors of $\mathrm{CoTiNb}_{2} \mathrm{O}_{8}$ and $\mathrm{ZnNb}_{2} \mathrm{O}_{6}$, respectively. The results calculated by the formula are shown in Fig. 8(b). It can be seen that the measured $Q \times f$ values for intermediate components were significantly lower than the theoretical values. The dielectric loss of materials at microwave frequencies could be divided into two categories: one is the intrinsic loss, which is mainly controlled by the lattice vibration mode; the other one is the external loss, 

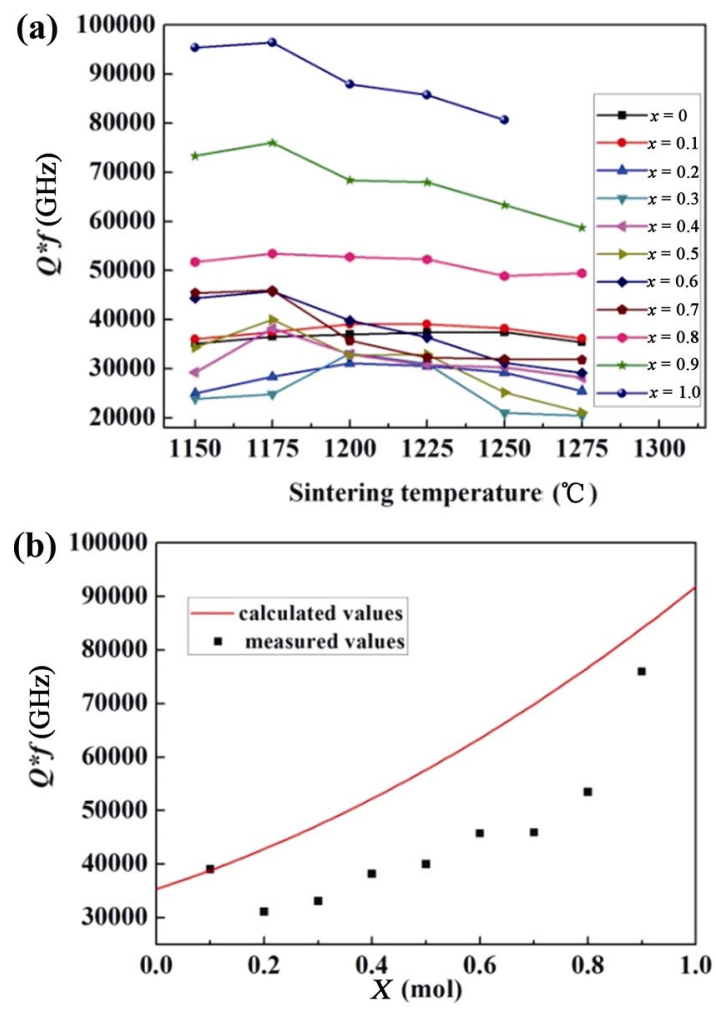

Fig. 8 (a) $Q \times f$ values of $(1-x) \mathrm{CoTiNb}_{2} \mathrm{O}_{8}-x \mathrm{ZnNb}_{2} \mathrm{O}_{6}$ ceramics as a function of sintering temperatures, and (b) the variety of $Q \times f$ values of $(1-x) \mathrm{CoTiNb}_{2} \mathrm{O}_{8}-x \mathrm{ZnNb}_{2} \mathrm{O}_{6}$ ceramics with $x$ values.

which is mainly affected by the combined effects of the second phase, the oxygen vacancy, the grain size, and the compactness $[28,29]$. For the intermediate components of the composite, the grain size was smaller than that of the single phase (Fig. 5) which led to the increase of the grain boundaries and micro porosities, and the decrease of $Q \times f$ values. For the samples of $0.2<x<$ 0.4 , the effect of the increasing amounts of grain boundaries caused by the sharp decrease of grain sizes on the $Q \times f$ values could be greater than that of samples with small $x$ values.

The $\tau_{f}$ values of $(1-x) \mathrm{CoTiNb}_{2} \mathrm{O}_{8}-x \mathrm{ZnNb}_{2} \mathrm{O}_{6}$ composite ceramics as function of $x$ are revealed in Fig. 9. With the increase of $x$ values, the $\tau_{f}$ values reduced from +108.04 to $-49.31 \mathrm{ppm} /{ }^{\circ} \mathrm{C}$. For samples of $x=0.5$, the $\tau_{f}$ values reached $3.57 \mathrm{ppm} /{ }^{\circ} \mathrm{C}$. It is obvious that near zero temperature coefficient of resonant frequency can be obtained between $x=0.5$ and $x=0.6$. With the increasing $x$, the reason for the increase of the $\tau_{f}$ value can be attributed to the positive temperature coefficient of resonant frequency of $\mathrm{ZnNb}_{2} \mathrm{O}_{6}$ ceramics. The temperature coefficient of resonant frequency of $(1-x) \mathrm{CoTiNb}_{2} \mathrm{O}_{8}-x \mathrm{ZnNb}_{2} \mathrm{O}_{6}$ can

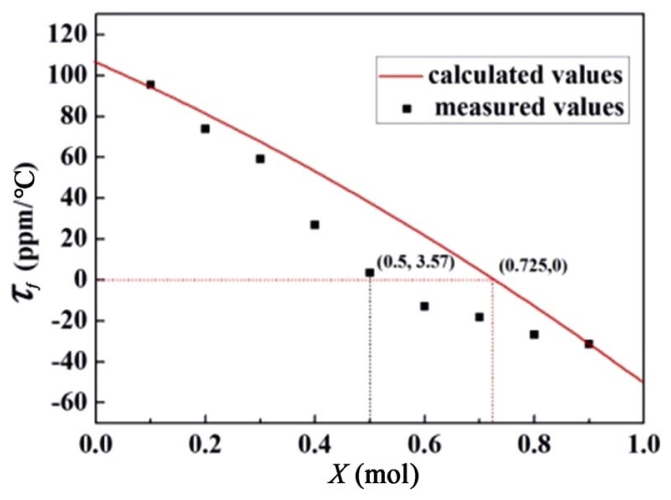

Fig. 9 Temperature coefficients of resonant frequency of $(1-x) \mathrm{CoTiNb}_{2} \mathrm{O}_{8}-x \mathrm{ZnNb}_{2} \mathrm{O}_{6}$ ceramics sintered at the optimum sintering temperature.

be calculated according to the following formula [27, 30]:

$$
\tau_{f}=v_{1} \tau_{f 1}+v_{2} \tau_{f 2}
$$

where $\tau_{f}$ is the temperature coefficient of the resonant frequency of the $(1-x) \mathrm{CoTiNb}_{2} \mathrm{O}_{8}-x \mathrm{ZnNb}_{2} \mathrm{O}_{6}$ ceramics, $v_{1}$ and $v_{2}$ are the volume fractions of $\mathrm{CoTiNb}_{2} \mathrm{O}_{8}$ and $\mathrm{ZnNb}_{2} \mathrm{O}_{6}$, respectively; $\tau_{f 1}$ and $\tau_{f 2}$ are the temperature coefficients of the resonant frequency of $\mathrm{CoTiNb}_{2} \mathrm{O}_{8}$ and $\mathrm{ZnNb}_{2} \mathrm{O}_{6}$, respectively. Figure 9 shows the calculated temperature coefficients of the resonant frequency curve. The variation of the temperature coefficients of resonant frequency with the component was different from the expected calculated values. The calculated zero temperature coefficient of the resonant frequency was obtained when $x$ was around 0.725 . When $x$ was between 0.2 and 0.8 , the measured values were lower than the expected calculated values and the temperature coefficient point of zero resonance frequency when $x$ was around 0.5. This phenomenon may be attributed to the transition of the crystal structure with different $x$ values in composite ceramics. The peak intensities of $\mathrm{CoTiNb}_{2} \mathrm{O}_{8}$ and $\mathrm{ZnNb}_{2} \mathrm{O}_{6}$ in the Raman spectra should be the same because of the same content of the two phases at $x=$ 0.5. But as shown in Fig. 4, the peak located at $684 \mathrm{~cm}^{-1}$ in the vibrational mode of $\mathrm{CoTiNb}_{2} \mathrm{O}_{8}$ has disappeared at $x=0.5$. The main phase was the columbite phase of $\mathrm{ZnNb}_{2} \mathrm{O}_{6}$. It was revealed that the solid solution in the composite ceramic with $x=0.5$ was mainly $\mathrm{ZnNb}_{2} \mathrm{O}_{6}$ based solid solution. Because the $\tau_{f}$ values of $\mathrm{ZnNb}_{2} \mathrm{O}_{6}$ was negative, the measured values were lower than the calculated values, which led to the early appearance of the near zero temperature coefficient of the resonance frequency. This effect and 
the increase in the content of $\mathrm{ZnNb}_{2} \mathrm{O}_{6}$ led to a rapid decrease in the temperature coefficient of the resonance frequency and the near zero temperature coefficient of the resonance frequency was obtained at a smaller $x$ value.

\section{Conclusions}

Crystal structure and microwave dielectric properties of $(1-x) \mathrm{CoTiNb}_{2} \mathrm{O}_{8}-x \mathrm{ZnNb}_{2} \mathrm{O}_{6}$ ceramics with controlled temperature coefficient were studied in this work. The influence of the addition of $\mathrm{ZnNb}_{2} \mathrm{O}_{6}$ on the crystal structure was analyzed in detail using a combination of X-ray diffraction, Raman spectra, and scanning electron microscopy. The system remained rutile phase structure until $x=0.2$ and the phase transition occurred between $x=0.3$ and $x=0.6$. When $x \geqslant 0.7$, the system maintained the columbite phase structure. The crystal structure had a significant influence on the dielectric properties of ceramics. Near zero temperature coefficient of the resonance frequency was obtained at $x=0.5$. The good densification of $0.5 \mathrm{CoTiNb}_{2} \mathrm{O}_{8}-0.5 \mathrm{ZnNb}_{2} \mathrm{O}_{6}$ ceramics could be achieved at $1175{ }^{\circ} \mathrm{C}$ for $4 \mathrm{~h}$ with $\varepsilon_{\mathrm{r}}$ value of $39.2, Q \times f$ value of $40013 \mathrm{GHz}$, and $\tau_{f}$ value of $+3.57 \mathrm{ppm} /{ }^{\circ} \mathrm{C}$.

\section{Acknowledgements}

This work has been financially supported by the National Natural Science Foundation of China (No. 51772022).

\section{References}

[1] Wu MJ, Zhang YC, Chen JD, et al. Microwave dielectric properties of sol-gel derived $\mathrm{NiZrNb}_{2} \mathrm{O}_{8}$ ceramics. $J$ Alloys Compd 2018, 747: 394-400.

[2] Wu MJ, Chen JD, Zhang YC. Effect of $\mathrm{B}_{2} \mathrm{O}_{3}$ addition on the microwave dielectric properties of $\mathrm{NiTiNb}_{2} \mathrm{O}_{8}$ ceramics. J Mater Sci: Mater Electron 2018, 29: 13132-13137.

[3] Baumgarte A, Blachnik R. New $\mathrm{M}^{2+} \mathrm{M}^{4+} \mathrm{Nb}_{2} \mathrm{O}_{8}$ phases. $J$ Alloys Compd 1994, 215: 117-120.

[4] Tseng CF. Microwave dielectric properties of low loss microwave dielectric ceramics: $\mathrm{A}_{0.5} \mathrm{Ti}_{0.5} \mathrm{NbO}_{4}(\mathrm{~A}=\mathrm{Zn}, \mathrm{Co})$. $J$ Eur Ceram Soc 2014, 34: 3641-3648.

[5] Wu MJ, Zhang YC, Xiang MQ. Structural, Raman spectroscopic and microwave dielectric studies on $(1-x) \mathrm{NiZrNb}_{2} \mathrm{O}_{8}-x \mathrm{ZnTa}_{2} \mathrm{O}_{6}$. J Mater Sci: Mater Electron 2018, 29: 14471-14478.

[6] Fu ZF, Ma JL, Liu P, et al. Novel temperature stable
$\mathrm{Li}_{2} \mathrm{Mg}_{3} \mathrm{TiO}_{6}-\mathrm{SrTiO}_{3}$ composite ceramics with high $Q$ for LTCC applications. Mater Chem Phys 2017, 200: 264-269.

[7] Nenasheva EA, Redozubov SS, Kartenko NF, et al. Microwave dielectric properties and structure of $\mathrm{ZnO}$ $\mathrm{Nb}_{2} \mathrm{O}_{5}-\mathrm{TiO}_{2}$ ceramics. J Eur Ceram Soc 2011, 31: 1097 1102 .

[8] Li WB, Zhou D, Xi HH, et al. Structure, infrared reflectivity and microwave dielectric properties of $\left(\mathrm{Na}_{0.5} \mathrm{La}_{0.5}\right) \mathrm{MoO}_{4^{-}}$ $\left(\mathrm{Na}_{0.5} \mathrm{Bi}_{0.5}\right) \mathrm{MoO}_{4}$ ceramics. J Am Ceram Soc 2016, 99: 2083-2088.

[9] Wise PL, Reaney IM, Lee WE, et al. Tunability of $\tau_{f}$ in perovskites and related compounds. J Mater Res 2002, 17: 2033-2040.

[10] Kim ES, Chun BS, Kang DH. Effects of structural characteristics on microwave dielectric properties of $(1-x) \mathrm{Ca}_{0.85} \mathrm{Nd}_{0.1} \mathrm{TiO}_{3}-x \mathrm{LnAlO}_{3}(\mathrm{Ln}=\mathrm{Sm}, \mathrm{Er}$ and $\mathrm{Dy})$ ceramics. J Eur Ceram Soc 2007, 27: 3005-3010.

[11] Lee HJ, Kim IT, Hong KS. Dielectric properties of $\mathrm{AB}_{2} \mathrm{O}_{6}$ compounds at microwave frequencies $(\mathrm{A}=\mathrm{Ca}, \mathrm{Mg}, \mathrm{Mn}, \mathrm{Co}$, Ni, Zn, and B = Nb, Ta). Jpn J Appl Phys 1997, 36: L1318L1320.

[12] Toby BH. EXPGUI, a graphical user interface for GSAS. $J$ Appl Cryst 2001, 34: 210-213.

[13] Hakki BW, Coleman PD. A dielectric resonator method of measuring inductive capacities in the millimeter range. IEEE Trans Microwave Theory Techn 1960, 8: 402-410.

[14] Courtney WE. Analysis and evaluation of a method of measuring the complex permittivity and permeability microwave insulators. IEEE Trans Microwave Theory Techn 1970, 18: 476-485.

[15] Kobayashi Y, Katoh M. Microwave measurement of dielectric properties of low-loss materials by the dielectric rod resonator method. IEEE Trans Microwave Theory Techn 1985, 33: 586-592.

[16] Abrahams I, Bruce PG, David WIF, et al. Structure determination of substituted rutiles by time-of-flight neutron diffraction. Chem Mater 1989, 1: 237-240.

[17] Xu DP, Liu Y, Zhou Q, et al. Optical phonon behaviors of columbite $\mathrm{ZnNb}_{2} \mathrm{O}_{6}$ single crystal. J Alloys Compd 2015, 618: 694-699.

[18] Husson E, Repelin Y, Dao NQ, et al. Normal coordinate analysis of the $\mathrm{MNb}_{2} \mathrm{O}_{6}$ series of columbite structure $(\mathrm{M}=$ Mg, Ca, Mn, Fe, Co, Ni, Cu, Zn, Cd). J Chem Phys 1977, 67: 1157-1163.

[19] Huang FX, Zhou Q, Ma CL, et al. High pressure Raman scattering and X-ray diffraction studies of $\mathrm{MgNb}_{2} \mathrm{O}_{6}$. RSC Adv 2013, 3: 13210-13213.

[20] Maeda M, Yamamura T, Ikeda T. Dielectric characteristics of several complex oxide ceramics at microwave frequencies. Jpn J Appl Phys 1987, 26: 76-79.

[21] Bezrodna T, Gavrilko T, Puchkovska G, et al. Spectroscopic study of $\mathrm{TiO}_{2}$ (rutile)-benzophenone heterogeneous systems. J Mol Struct 2002, 614: 315-324.

[22] Zhang Y, Zhang YC, Xiang MQ. Crystal structure and microwave dielectric characteristics of $\mathrm{Zr}$-substituted 
CoTiNb $_{2} \mathrm{O}_{8}$ ceramics. J Eur Ceram Soc 2016, 36: 19451951.

[23] Zhang J, Zuo RZ, Cheng Y. Relationship of the structural phase transition and microwave dielectric properties in $\mathrm{MgZrNb}_{2} \mathrm{O}_{8}-\mathrm{TiO}_{2}$ ceramics. Ceram Int 2016, 42: 76817689.

[24] Husson E, Repelin Y, Dao NQ, et al. Normal coordinate analysis for $\mathrm{CaNb}_{2} \mathrm{O}_{6}$ of columbite structure. J Chem Phys 1977, 66: 5173-5180.

[25] Ramarao SD, Kiran SR, Murthy VRK. Structural, lattice vibrational, optical and microwave dielectric studies on $\mathrm{Ca}_{1-x} \mathrm{Sr}_{x} \mathrm{MoO}_{4}$ ceramics with scheelite structure. Mater Res Bull 2014, 56: 71-79.

[26] Hanai T. Theory of the dielectric dispersion due to the interfacial polarization and its application to emulsions. Kolloid-Zeitschrift 1960, 171: 23-31.

[27] Huang CL, Weng MH. Improved high q value of $\mathrm{MgTiO}_{3^{-}}$ $\mathrm{CaTiO}_{3}$ microwave dielectric ceramics at low sintering temperature. Mater Res Bull 2001, 36: 2741-2750.

[28] Kim WS, Kim TH, Kim ES, et al. Microwave dielectric properties and far infrared reflectivity spectra of the $\left(\mathrm{Zr}_{0.8} \mathrm{Sn}_{0.2}\right) \mathrm{TiO}_{4}$ ceramics with additives. Jpn J Appl Phys
1998, 37: 5367-5371.

[29] Sagala DA, Nambu S. Microscopic calculation of dielectric loss at microwave frequencies for complex perovskite $\mathrm{Ba}\left(\left(\mathrm{Zn}_{1 / 3} \mathrm{Ta}_{2 / 3}\right) \mathrm{O}_{3}\right.$. J Am Ceram Soc 1992, 75: 2573-2575.

[30] Lv Y, Zuo RZ, Cheng Y, et al. Low-temperature sinterable $(1-x) \mathrm{Ba}_{3}\left(\mathrm{VO}_{4}\right)_{2}-x \mathrm{LiMg}_{0.9} \mathrm{Zn}_{0.1} \mathrm{PO}_{4}$ microwave dielectric ceramics. J Am Ceram Soc 2013, 96: 3862-3867.

Open Access This article is licensed under a Creative Commons Attribution 4.0 International License, which permits use, sharing, adaptation, distribution and reproduction in any medium or format, as long as you give appropriate credit to the original author(s) and the source, provide a link to the Creative Commons licence, and indicate if changes were made.

The images or other third party material in this article are included in the article's Creative Commons licence, unless indicated otherwise in a credit line to the material. If material is not included in the article's Creative Commons licence and your intended use is not permitted by statutory regulation or exceeds the permitted use, you will need to obtain permission directly from the copyright holder.

To view a copy of this licence, visit http://creativecommons.org/licenses/by/4.0/. 